\title{
Pragmatism and International Relations
}

A Story of Closure and Opening

\section{Molly Cochran}

\section{(2) OpenEdition}

Electronic version

URL: http://journals.openedition.org/ejpap/777

DOI: 10.4000/ejpap. 777

ISSN: 2036-4091

\section{Publisher}

Associazione Pragma

Electronic reference

Molly Cochran, «Pragmatism and International Relations », European Journal of Pragmatism and American Philosophy [Online], IV - 1 | 2012, Online since 23 July 2012, connection on 01 May 2019. URL : http://journals.openedition.org/ejpap/777 ; DOI : 10.4000/ejpap.777

This text was automatically generated on 1 May 2019.

\section{c) $(9 \ominus$}

Author retains copyright and grants the European Journal of Pragmatism and American Philosophy right of first publication with the work simultaneously licensed under a Creative Commons AttributionNonCommercial-NoDerivatives 4.0 International License. 


\title{
Pragmatism and International Relations
}

\author{
A Story of Closure and Opening
}

\author{
Molly Cochran
}

\section{AUTHOR'S NOTE}

I would like to acknowledge the assistance, editorial and custodial, of the Keenes: Eddie and my in-laws, Gillian and David. Thank you.

\section{Introduction}

1 Charles Pierce did not write on international relations, but both William James and John Dewey did. James was a member of the Anti-Imperialist League; he criticised US foreign policy in editorials and essays concerning America's involvements in the Philippines, especially its war against Filipinos fighting for independence after the US acquired the Philippines in 1898. James also wrote on the theme of redirecting energies for war through alternative, peaceful channels. The idea is first broached in The Varieties of Religious Experience and then developed in his essay, "The Moral Equivalent of War."1 Dewey was even more prolific on international relations: his writings include reflections on topics such as coercion and the use of force, war and democracy, the role of America in the world, American entry into the League of Nations, the outlawry of war, and the World Court (see Cochran 2010).

2 Yet, neither James nor Dewey features as a significant figure in accounts of the evolution of the academic discipline of International Relations (IR). This absence is especially remarkable in Dewey's case, in view of the sheer extent of his writing on the subject; the fact that it appeared in widely-read journals such as The New Republic and Foreign Affairs; and his stature as a major public intellectual during the formative period when the 
academic study of IR was being institutionalised. The experience of World War I, and the hope of avoiding another war like it, generated an interest in the systematic study of war and peace as a dedicated academic discipline: the first Chair in the subject, the Woodrow Wilson Chair of International Politics at the University of Wales at Aberystwyth, was established in 1919. ${ }^{2}$ The zenith of American Pragmatism thus overlapped with the development of IR as a social science. But a survey of histories of the discipline reveals no reference to the philosophy of Pragmatism, despite an early connection in the field with political theory and classical thought about international politics stretching back to Thucydides. ${ }^{3}$ Through all of these histories I have found just one mention of a Pragmatist, and that is a relatively brief nod to Dewey as an influence on others (Schmidt 1998: 99).

3 I am careful to write that there is no mention of the philosophy of Pragmatism, because 'pragmatism' (with a small ' $p$ ') is a word that appears regularly in studies of international relations, most typically when being distinguished from the application of moral principle in world affairs. Indeed, it is widely argued that, in a world of diverse states, each with its own interests and often competing with one another to survive, it is foolhardy to act in line with what moral principle demands rather than what prudence dictates. We are told that the statesman shapes policy in line with the national interest, knows the facts of existing conditions, and pays special attention to power and its alignments. This understanding, attributed to the school of 'realism' in IR, attaches moral value only to responsible action that pragmatically adapts policy to circumstances. I will argue later that the potential value of Pragmatism to normative theorizing in IR is something different from this position; but it should be acknowledged that, like realists, Pragmatists would be loathe to apply moral absolutes to matters of international relations; attention must be given to the particular context of a problematic situation.

So where are the Pragmatists in IR? The application of American Pragmatism ${ }^{4}$ to the social science of IR has suffered in two key respects, which stem from a central concept and surrounding discourse that runs through the history of the discipline: the anarchy problematique. The fact that international politics, unlike domestic politics, lacks an overarching central authority is a major organizing element of scholarship within the field. In one of its most stark formulations, anarchy is taken to imply that there is little scope for political philosophy or theory in the international realm, since, as Martin Wight famously wrote, those are forms of inquiry "appropriate to man's control of his social life [...] the theory of the good life. International theory is a theory of survival" (1966: 33). The thinking goes that neither American pragmatism, nor any other set of philosophical ideas, can have purchase in this field of material forces. This is the first problem for pragmatism in IR, and it is an ontological one: if the fact of anarchy structures all that goes on in world affairs, then what scope is left for Dewey's key concerns of theorizing change and improving societal and inter-societal conditions?

5 The second difficulty is related to the fact of anarchy as a habit of thinking in the discipline, but is epistemological rather than ontological. What do we know, and can we know, about international relations? The discipline experienced a behavioral revolution at a time when the anarchy problematique was being felt acutely: particularly in America, the advent of the atomic age and the context of the Cold War made the development of a science of international politics an urgent requirement. Stanley Hoffmann has described IR as an 'American' social science defined by its positivist proclivities and its will to make the study of international politics a policy science, a 'how-to' guide for wielding American power in its post-World War II, global role. Thus, despite the existence of a rich, 
philosophically-inspired historical tradition of international political thought (see Brown, Nardin \& Rengger 2002), IR has not maintained a strong connection with political theory or philosophy since its turn to positivism, but has oriented itself towards a presentist vision of policy-relevant science.

However, the bedrock of positivism that has dominated the discipline since the latter half of the 1950s has experienced fissures of late. Confidence in the positivist schools that came to dominate the field since the 1970s, 'neorealism' and 'neoliberalism,' was fundamentally shaken by the failure of scholars to anticipate the events of 1989 that ended the Cold War and led to the break-up of the Soviet Union. ${ }^{5}$ What, then, of prediction and control? An opening for interpretive approaches was created, and while many of these adopted a form of "constructivism" that aimed largely to fill explanatory gaps with ideational causes - a kind of IR positivism 2.0 - deeper challenges to positivism emerged. In 1989, Yosef Lapid declared the advent of a post-positivist era. New approaches challenged both the anarchy problematique and the aims of prediction and control that had been at the center of the discipline for so long. The 1990s brought developments in normative IR theory, a revival of the classical approach of the English School, feminist IR theory, and historical materialism and IR. It is in this milieu of a new post-positivist phase of thinking in IR that pragmatism has found a point of entry. When Steve Smith wrote the introduction to International Theory: Positivism and Beyond in 1996, he posed the question, "if we wish to open epistemological space for alternatives to an international relations based on empiricism, what other epistemologies are available" (1996: 22-3). His answer was that the options were two: either a discredited rationalism or pragmatism. However, in his survey of the emerging post-positivist approaches to IR at the time, there was little pragmatism in sight.

7 Today is a different story. Jörg Friedrichs and Fredrick Kratochwil recently set out a program to introduce an alternative methodological approach in IR based on American pragmatism that could "reconcile scientific inquiry with the requirements of practical reason" (2009: 703). Special issues on the topic of pragmatism and IR have been published in Millennium: Journal of International Studies, the Journal of International Relations and Development, and the International Studies Review in 2002, 2007 and 2009 respectively. Here I will argue that this is a critical moment to take stock of these developments, and reflect on where they are heading. First, in order to understand what pragmatism might bring to IR as a social science today, it is important to examine its history and explain why pragmatism appears not to have registered in its past. Why, as I noted above, have the contributions of James and, especially, Dewey apparently disappeared from the early history of the field? Secondly, having examined what the problem was before, I go on to argue that the opportunity that exists today for pragmatism to influence the field is constructed upon its critique of empiricist epistemology, its anti-positivist credentials so to speak; its scope for bridging plural methods; and the broadening of our understanding of what international relations is, opening the range of possible ontological claims which the discipline finds necessary at this time.

\section{A Historical Puzzle: Where are the Pragmatists?}

Lucian Ashworth writes that the discipline of IR "is a twentieth century product of predominantly liberal Enlightenment concerns" (1999: 1). This raises a puzzle: why does John Dewey, an important figure writing on themes of liberal internationalism in his day, 
not really feature? Ashworth is clear that his account is a revisionist account, challenging the legacy of Thucydides, Machiavelli and Hobbes in the field. However, his point is that their writings are not examples of IR scholarship. Instead, these writers are primarily interested in the domestic polity and remark on the international as a side note to the extent that an external dimension intercedes upon thought about the domestic. Ashworth's claim is that Enlightenment thinkers - Hegel being an important exception linked an international project of perpetual peace to their plans for the domestic polity. Enlightenment themes of progress, political emancipation and the development of human freedom were transposed onto the international.

Some argue that IR grew into a discipline from thinking of this kind represented in action and popular journalism. W.T.R. Fox (1967: 2) attributed interest in the study of international relations to the nineteenth century peace movements, of which James was a member, and wrote that this generated an interest in arbitration and international law as a vehicle for eliminating war, an activism that Dewey took an important position in when he became a leading proponent of Salmon O. Levinson's Outlawry of War movement after WW I. Dewey wrote on many themes important to liberal internationalists, such contributions making up almost half of two volumes of Characters and Events: Popular Essays in Social and Political Philosophy in which Joseph Ratner collected Dewey's political journalism in 1929. What unifies these writings is an underlying concern that the moral inclusion of individuals be made effective in the relations between states, that a new diplomacy should arise out of the destruction of WW I that would give recognition to the humanity of each individual and assist in the development of human capacities, making manifest the idea of democracy in international affairs. Kant and Dewey got there in different ways, but each - like the early 20th century IR scholars Ashworth discusses wanted to see moral value attributed to individuals in the sphere of international politics.

And yet, if one searches not only histories of the discipline, but the books and articles written by early contributors to IR, it is clear that Dewey was not regarded by them as 'one of us.' He does receive mention as an important figure lending his name and stature to the cause of liberal internationalism, but he was not seen as a scholar of international relations as such. Why? It is striking that the language Ashworth uses when he writes about early IR scholars, such as Alfred Zimmern, H. N. Brailsford, Norman Angell and David Mitrany, is that they made international relations the primary focus of their work (1998: 4). At some level this must be right and relevant to our puzzle here. International relations was not the primary focus of Dewey's work. Dewey was a philosopher whose intellectual interests drew him not only to politics and international relations, but psychology, education, religion, art and aesthetics. Given the breadth of his interests at a time of the narrowing and professionalization of academic pursuits, it would have been rather remarkable for him to have made a impact on the new discipline of IR in addition to the other disciplines he is known to have influenced: psychology and education studies especially.

11 However, the 'who' generating IR theory in the early 20th century was reasonably fluid in the sense that it was not being created by academics sitting in IR departments or by academics alone. As David Long writes, IR was "a fledgling social science in 1919; as such, there were few international theorists in the disciplinary sense," and not even in the 1920 s or 1930 s do we see the field professionalized; "There was therefore a space for writers and publicists not located in an academic setting" (Long 1995: 303). So, if international relations theory was being created by academics who focused on IR, but did 
so from departments of history, law, and later politics and economics, and by nonacademic writers - e.g. a journalist like Walter Lippmann - why not Dewey as an academic philosopher who wrote about the nature of the international, and not just on external aspects as they related to a theory of the state? What is so striking in relation to this question is that themes one finds in Dewey's writings match up with those Long identifies in the non-academic IR he surveys. Among the academics writing non-academic IR he includes Laski - particularly interesting given what follows below - or those outside academe like J. A. Hobson, who were often writing on topics that preoccupied Dewey too: interdependence, the democratic control of international relations, non-state actors, and thinking about functionalism in the context of the international realm (Long 1995: 309; Cochran 2010). The volume and quality of his writing on these themes do not appear to have been sufficient to have made an indelible mark on the field. It remains a puzzle that will be raised, but not answered in this article. Nevertheless, Dewey had an indirect impact upon International Relations, and one that I will argue grows more important for the trajectory of IR as a discipline into its future.

\section{Dewey and the Theory of State Literature in the Pre- history of IR}

12 I mentioned above that the sole, brief, tantalizing, reference to Dewey appears in Brian Schmidt's study, The Political Discourse of Anarchy, where he draws our attention to work in the early days of Political Science on the theory of the state, and claims that its discussion was important not only to the development of Political Science, but IR as well. Schmidt traces the pre-history of IR to the early 1880s, when the first school of political science opened at Columbia College. Early on, an influential paradigm emerged that anchored the discourse of political science in the theory of the state, mimicking the German Staatslehre (1998: 54). As the theory of the state developed in the late 19th century, it became the context in which both political science and the study of international relations took shape. According to Schmidt, "[t]he ontology of international relations, the character of international law, the possibility of a world state, the extent to which there was international organization and cooperation among states were all determined with respect to the theory of the state" (1998: 76). Its influence was substantial in founding the discipline and Dewey made a crucial intervention on the topic in 1874 in a commentary on the theory of the state as discussed by John Austin. According to Schmidt, Dewey's views were picked up and expounded upon by an important scholar for the new discipline, Harold Laski.

13 In this pre-history, an early orthodoxy emerged in the form of the juridical theory of the state, the conception of which owed much to Hobbes, Bodin and Austin. Schmidt notes that W. W. Willoughby's treatment of the juridical state was foundational to the discourse that developed in the 1900s, and the idea of international relations that he developed borrows from Austin (1998: 88-9). Austin's belief that natural law can command no force with individuals in a state of nature was transposed by Willoughby onto international relations when he argued that like a person, the state has a will of its own and is "legally supreme" ${ }^{16}$ with natural law having no more command over it than over individuals in a state of nature. This opened the discourse of anarchy that would, as Schmidt argues, feature throughout the development of IR as a discipline. ${ }^{7}$ In this formal, juridical notion of the state formulated by Willoughby and others in the early 20th century, the core 
principle of the state was sovereignty, and sovereignty was its "legitimating will." It is Schmidt's contention that juristic conceptions of the state came to be challenged in ways that were deeply influenced by the philosophy of pragmatism (1998: 99). In his essay, "Austin's Theory of Sovereignty," Dewey wrote that in Austin "there is a confusion of sovereignty with the organs of its exercise, and that this confusion has for its result a radical error concerning the mode in which sovereignty is exercised - an error which, so far as acted upon, is likely to result in harm" (EW4: 73). Why? Dewey argued that:

in every existing civilized state governmental power is in the hands of a certain body of persons, capable of more or less accurate assignment and thus Austin's conception seems to agree fairly with facts. But that there are such determinate governments, is a matter lying quite outside the range of Austin's theory; they exist precisely because large social forces, working through extensive periods of time, have fixed upon these governments as organs of expression. It is these forces, gradually crystallizing, which have determined governments and given them all the specific (determinate) character which they now possess. Take away the forces which are behind governments - which have made them what they are, and the existence and character of these governments is an accident, likely to be changed at any moment. Admit these forces, and, since they determine the government, they are sovereign. (EW4: 80) $)^{9}$

14 According to Schmidt, Dewey's argument resonated with Harold Laski and influenced Laski's important pluralist critique of the juridical theory of the state that gained considerable momentum in the 1920s. Schmidt does not provide textual evidence for the claim, however, Laski certainly read Dewey, and referred to Dewey's essay on Austin in his book, The Foundations of Sovereignty and Other Essays (1921). Laski was working at the New Republic when Dewey was one of its regular contributors.

The emerging pluralist position, as Ellen Deborah Ellis characterized it in 1920, was to deny "the essential unity and absoluteness of the state and sovereignty." ${ }^{10}$ Dewey made his own contribution in 1920 when he asked whether the state

is not just an instrumentality for promoting and protecting other and more voluntary forms of association, rather than a supreme end in itself [...] As they [voluntary associations] develop in number and importance, the state tends to become more and more a regulator and adjuster among them; defining the limits of their actions, preventing and settling conflicts. (MW 12:196)

Dewey likened the state to the conductor of an orchestra, saying the "state remains highly important - but its importance consists more and more in its power to foster and coordinate the activities of voluntary groupings." Those groupings, which promote a diversity of goods, are the "real social units," not states for Dewey. Thus, Dewey claims that "[p]luralism is well ordained in present political practice and demands a modification of hierarchical and monistic theory" (MW 12: 196). It is also important to note here that Dewey did not fail to comment on pluralism in relation to the international sphere, writing that: 1) the "abnormally supreme position" that states assume in war has led to the "increased demoralization" of the institution of war; and 2) that voluntary associations "do not coincide with political boundaries," but are transnational. In general, there has been a "growth" of the international, of which these unbounded voluntary associations are a part. Thus, he concludes that "internationalism is not an aspiration but a fact, not a sentimental ideal but a force" which compromises the traditional dogma of exclusive national sovereignty. It is the vogue of this doctrine, or dogma, that presents the strongest barrier to the effective formation of an international mind" (MW 12: 197). ${ }^{11}$ 

the juridical theory of the state. His aim was to reconstruct political theory such that it reflected "institutions more fitted to the needs we confront"; that is, a pluralistic state that substitutes "coordination for a hierarchical structure" (Laski 1921: vii). Like Dewey, Laski argues that human association manifests itself in many ways and believes these voluntary associations to be important, possessing a kind of sovereignty in themselves which runs counter to the monist's assertion that the sovereignty of the state is indivisible or omnipotent. However, as Schmidt points out, Laski's empirical assertion is followed by a normative one, and we find the same in Dewey too: the claim that the sovereign state is not an end in itself, deserving of the moral rights conferred on it by a now compromised juridical theory of the state. As Laski writes, "advocates of pluralism are convinced that this is both administratively incomplete and ethically inadequate."12 Finally, there are international implications of the pluralist critique for Laski as well. The juridical theory of the state was getting in the way of thinking about the international realm properly, and that it was "only by the abrogation of the idea of sovereignty in international affairs that is there any real prospect of the working of international ideas being placed upon a basis at once successful and sound" (Laski 1927: 290). commentary on the external features of sovereignty as it pertained to a political theory of the state. And Dewey played, at the very least, an indirect part in this transformation, shaping the pluralism that directed the study of IR towards ways of thinking about the facts of international interdependence, and about how to manage it better than the juridical sovereign state concept had made possible. Along with the pluralism that impacted and influenced interwar IR came a will to mitigate the effects of anarchy and reform international relations, placing the study of international organization at the center of what IR does. And it is important to underscore now, because of the direction the study of IR took after WW II, and the tar of "utopianism" that E. H. Carr's book The Twenty Years' Crisis: 1919-1939 brushed over the work of liberal internationalists, that it did so not out of wishful, idealistic thinking, but out of keen attention to reality: their world was strikingly global and a new interstate organization for managing the growth of international forces that were reaching beyond the control of sovereign states - The League of Nations - had emerged. These phenomena required careful, dedicated study. ${ }^{13}$ Dewey agreed. Rebuilding after WW I required an acknowledgement that the Westphalian model of state sovereignty was an anachronism; that a new diplomacy was needed to coordinate cooperation in directing the forces of interdependence so as to improve the life chances of all, rather than the interests of states narrowly interpreted; and that trans-boundary voluntary associations should unite as international publics to assist in shaping a more inclusive world politics, not leaving it to states alone (Cochran 2010).

The scholarly concerns of Dewey and the liberal internationalists were bracketed in the discipline for a good fifty or more years. The naiveté associated with liberal internationalism has been so great as to hide from view the connection of their pluralism with forms of pluralist critique that were to follow later in the discipline that shone light on cooperation and actors other than states in world affairs, e.g. transnationalism, functionalism, and complex interdependence (Schmidt 1998: 237). Additionally, their marginalization would not only narrow what was seen in the world as worthy of empirical investigation, but it would put a brake on normative inquiry almost altogether. Remember, the challenge of pluralism was an empirical as well as a normative challenge 
to the prevailing theory of the state. After WW II, the anarchy problematique submerged the interest that pluralists such as Dewey and Laski had demonstrated in questions of justice and the moral inclusion of individuals in world politics. It would not be until the rekindling of normative theory in IR in the late 1980s and early 1990s that a passage such as Laski's would resonate again:

[p]olitically, in its judgment of what it is entitled to do, a state considers not the interest of humanity as a whole, not the obvious precepts of judgment and right, but the basest considerations of expediency, as it chooses to interpret them. A state becomes, in short, the judge of its own cause, and it is elementary that that is a denial of justice. (Laski 1927: 290)

As we shall now see, that would be an important opening for Dewey too, in which he would feature not only in the normative IR literature, but in 21st century calls for reexamining methodologies in IR.

\section{Emerging from a Deep Winter. Pragmatism and Contemporary IR}

The IR discipline may have grown out of liberal Enlightenment concerns, but such concerns experienced a deep winter. As I indicated in the introduction, this was not only due to the ontological implications of the anarchy problematique. The winter was made harsher by methodological preoccupations of molding IR into a proper science. IR scholarship during the interwar years was not without aims to science, but these aims were not as yet backed by the full-blown positivism that was to develop after IR experienced its behavioral revolution in the mid-1950s.

The influence of pragmatism in philosophy had long since waned as well, overtaken by analytical philosophy. However, before the aim of replacing "ideographic statements with empirical generalisations" (Wilson 1998: 10) won the day, realist scholars such as Reinhold Neibuhr and Hans Morgenthau who formulated their thought more traditionally in terms of organizing ideas and concepts, did engage with pragmatism, and Dewey's philosophy in particular (Bauer \& Brigi 2009: 165). This engagement does not register in the discipline either, even though realism's own brand of traditionalism held sway for some time beyond the mid-1950s in the work of not just Morgenthau and Neibuhr, but Henry Kissinger, George Kennan, Raymond Aron, John Herz, and Martin Wight. ${ }^{14}$ Science was not their plea, but rather the need to shift the focus of IR onto power and politics, over cooperation and international law and organization. Attention was thrown back onto sovereign states and their rational will as unitary actors to seek power and calculate interest in terms of power. The Hobbes-Austinian theory of the state that Dewey had criticised was back with a vengeance.

Positivism settled upon the discipline in waves that grew more forceful over time. Positivism in IR is unified by four basic propositions: 1) belief in the unity of science; 2) commitment to a strict fact/value separation; 3) belief in the existence of regularities in the social as well as the natural world that licenses deductive-nomological and inductivestatistical forms of covering law explanation; and 4) empirical validation, falsification, being viewed as proper inquiry (Smith 1996: 16). Positivism hit IR as behaviorism in the way it did across the social sciences in the mid-20th century. The behavioralists looked for eternal laws of international politics left uninvestigated within the classical foundations of realism. The avowed 'scientists' began to take a grip on the IR discipline 
beginning in the late 1950s. Morton Kaplan's book, System and Process in International Politics (1957) is an exemplar and demonstrates "a firm commitment to the noncircular objectivity of science" (Kaplan 2000: 696). However, at the same time, a traditional realism of the kind found in the English School, registered a challenge: Hedley Bull's critique of the American science of IR from the vantage point of his particular "classical approach" (Bull 1966). More theoretical challenges were to follow, what Michael Banks labels "post-behavioralism" in IR, exemplified by John Burton's cobweb model of international relations as opposed to the classic billiard ball model of realism that was carried forward by the scientists. ${ }^{15}$ These challenges of the late 60 s were followed by the rise of theories of transnationalism and interdependence that were a reaction to the weakness of states in the face of challenges like the oil crisis of the early 1970 s.

The next significant positivist wave hit as détente gave way to a second Cold War, and realism resurged in the form of a structural explanation for the logic of power politics, provided by Kenneth Waltz in his book, Theory of International Politics (1979). Waltz's structural realism, or neorealism as work of this genre also came to be known, represented the high tide of positivism that took hold of the discipline for approximately ten years. While the neoliberal critique continued to flourish, growing out of work on transnationalism, complex interdependence and later regime theory, it was only a mild ontological tweaking of the anarchy problematique; it held that states remained the most significant actors and that power and politics should continue to be the focus of attention in IR, but stressed that a realm of cooperation in the rules, norms, principles and institutions of international politics existed. But, while it echoed the earlier liberal belief in the possibility of international organization, "neoliberalism" did not share their normative concerns, and it cannot be construed as an epistemological challenge to neorealism. Indeed, neoliberal critics applauded structural realism for having put the discipline as a whole on a secure scientific footing, which is a powerful reason why this contemporary expression of pluralism was so out of touch with the interwar pluralists, and did not acknowledge its connection to ideas like those of Dewey.

This degree of epistemological dominance, such that even the challengers of the leading paradigm accepted its epistemological and methodological priorities with only a small qualification of what was to be the subject matter of IR, led to two reactions. First, some got busy generating the empirical data, either to substantiate the generalizable, structural theory of international competition set in motion by Waltz, or to round out that theory, examining how structural competition within anarchy impacted cooperation demonstrated in the system. Second, some desperately sought ways of thinking outside of the prevailing and powerful status quo, often by getting back to political theory and philosophy. Thus, pragmatism's first significant point of entry into contemporary IR was through Rorty's critique of the correspondence theory of truth, which was used in attempts to carve out a position beyond positivism in IR (Smith 1996, Cochran 1996, and Puchala 1995). Post-positivism has since gained a foothold, and new methodological avenues are being explored, as are the subjects fit for examination within the discipline. It is in this context that pragmatism is gaining significance for contemporary IR.

\section{Themes of Pragmatism in Contemporary IR}

26 "Readers of the contemporary literature in international relations [IR] increasingly find calls for a pragmatic reorientation in theorizing the field" (Kratochwil 2011: 200). Where 
a survey of the early period of IR yields little mention of American pragmatism, such a survey today produces rather different results. The majority of interventions on pragmatic themes, and the ones that resonate most in the discipline today, are those that aim to shed new light on the epistemological and methodological debates in which IR has been caught up since the 1970s. For example, Friedrich and Kratochwil write that they do not turn to pragmatism to be freed of such considerations; in the face of IR's failure to secure foundations of knowledge, to say "anything goes" is not an option. Instead, they use pragmatism "as an instrument to go about research with an appropriate degree of epistemological and methodological awareness" (2009: 707). What they value in pragmatism is its recognition that knowledge generation is a social, discursive activity, and that the aim of pragmatist inquiry is to produce useful knowledge. In particular, they believe abduction is a "good bet" as a Pragmatist research methodology for IR, not the only possible one, but the one they choose to develop. And they are not alone. Others invoke Peirce and abduction as a research methodology with benefits for IR (RytovuoriApunen: 2009; Finnemore 2003: 13; Ruggie 1998a: 94), however, Friedrichs, Kratochwil and Rytovuori-Apunen are the first to have provided a thorough engagement with what abduction represents methodologically; that is, the pragmatist philosophy that animates it. $^{16}$

27 Sil and Katzenstein are also of the view that the paradigmatic debates of IR could do with pragmatic interrogation. They advocate an opening out, a breaking of the constraints placed on social scientific inquiry in IR by "paradigm bound" scholarship, and propose that "analytic eclecticism," inspired by pragmatism, could prove to be fruitful in this respect. They describe as 'eclectic':

any approach that seeks to extricate, translate, and selectively integrate analytic

elements - concepts, logics, mechanisms, and interpretations - of theories or narrative that have been developed within separate paradigms but that address related aspects of substantive problems that have both scholarly and practical significance. (Sil \& Katzenstein 2010: 10)

28 Analytic eclecticism draws on pragmatism in three ways. First, it finds the success of a knowledge claim is in its practical consequences: whether, as Dewey writes, it helps scholars and citizens integrate 'knowing' and "doing.' Secondly, it takes from Rorty the idea that "there are no constraints on inquiry save conversational ones," and prioritizes inclusive dialogue with all who could be interlocutors. And thirdly, it draws on Mead's symbolic interactionism for its pragmatist understanding of agency, structure and identity (Sil 2009: 561). Sil and Katzenstein acknowledge that their appropriations may seem crude to those who know the philosophy of pragmatism well, but that the dialogue needs to get started, and once it has, what remains awkward in its appropriations from pragmatism and their implications for IR can be worked out along the way (2010: 47). ${ }^{17}$

A survey of pragmatist influences in the contemporary IR field yields much more besides. There are claims to pragmatism's benefit, and in some cases neo-pragmatism's (Rorty's), for the discipline in the following: bridge-building, synthesis and dialogue creation across IR paradigms (Sil \& Katzenstein 2010; Hellmann 2003; Checkel 2005; Cochran 2000); in theory cumulation or progress (Isacoff 2005; Chernoff 2004); as an alternative idea of what it means to be a social science (Jackson 2011 and 2010; Cochran 2002b); as a praxisbased philosophy (Friedrich \& Kratochwil 2009; Owen 2002; Bohman 2002); as a multiperspectival theory (Bohman 2002); for its invocation of language, metaphor, rhetoric (Sil \& Katzenstein 2010; Kornprobst 2009; Cochran 2001b); on ontology (Kurki 
2008); on debates about state-personhood (Franke \& Roos 2010); and for thinking about foundations for judgment, ethical or otherwise, in areas such as foreign policy making (Aalto 2011; Cochran 2001a), universal human rights (Wheeler \& Dunne 1998; Brown 1997), intervention (Bellamy 2002; Wheeler 1997), migrants (Parker \& Brassatt 2005); on boundaries (Festenstein 2002); public spheres, global and regional governance (Bray 2010; Wood 2011; Cochran 2010, 2008, 2002a; Bohman 2005; Brunkhorst 2002; Albert \& KoppMalek 2002).

To what do we owe this rich state of affairs? Pragmatism experienced a revival beginning in the 1980s in the form of the neo-pragmatisms of Richard Bernstein, Richard Rorty, and Hilary Putnam. Rorty's anti-representational epistemology and idea of cultural critique was an important source of IR's re-engagement with pragmatism just at the time it was looking for sources of philosophical inspiration, and it stimulated curiosity in the work of the classical pragmatists, especially Dewey, the writer to whom Rorty gave the most credit for influencing his approach to philosophy. This is significant, but so too is the constructivist turn in IR that is often credited for the blossoming of pragmatism in the field (Kratochwil 2011; Widmaier 2004).

Constructivism broke through to become the "third party" in what looked to be only a two-party, positivist system of IR scholarship; a breakthrough confirmed by the inclusion of constructivist thinkers in the 50th anniversary issue of International Organization on the topic of "Exploration and Contestation in the Study of World Politics" (Finnemore \& Sikkink 1998). According to Alexander Wendt, a key constructivist innovator, there are two basic insights behind the constructivist challenge to the "neo-neo" orthodoxy: first, "that the structures of human association are determined primarily by shared ideas rather than material forces"; and secondly, "that the identities and interests of purposive actors are constructed by these shared ideas rather than given by nature" (1999: 1). Thus, the causal powers attributed to the structure of the international system are not given, as assumed by neo-realists and neo-liberals, but instead, are shaped by the way anarchy is constructed in the social practices that exist between states; the way anarchy constrains is down to how anarchy is construed by state actors within the system. From this beginning, the reconnection with political theory, philosophy and social theory in American IR begins anew. As Wendt writes, the effects of anarchy could be something quite apart from what the anarchy problematique suggests; and manifest as Hobbesian, Lockean or even Kantian cultures (1999: 246-312). In view of our interest in the links between pragmatism and IR, it is significant that Wendt describes his own, highly influential, position - first presented in his often-cited 1992 article, "Anarchy is What States Make of It: the Social Construction of Power Politics," but significantly elaborated in his book, Social Theory of International Politics - as a synthesis of structuration theory and symbolic interactionism, modeled in large part upon the work of George Herbert Mead (Wendt 1999: 143).

It is therefore no surprise that one finds calls for a new "constructive pragmatism," or "pragmatic constructivism," to take the discipline beyond its paradigm debates and on towards dialogue, synthesis and progress in our knowledge (Kratochwil 2011; Hellmann 2003; Haas \& Haas 2002; Widmaier 2004). However, I would argue that these are unnecessarily conservative estimations of the benefit pragmatism can bring to the discipline. I agree with Rupra Sil, who writes

[c]onstructivism may be marginally more receptive to aspects of pragmatist thought (for example, Gould \& Onuf 2008; Haas \& Haas 2008), but most 
Constructivists in the United States remain 'conventional' (Checkel 2007) in the sense that their rejection of the ontologies underlying realism and liberalism has not been accompanied by a fundamental challenge to epistemological and methodological perspectives derived from analytic philosophy. (2009: 648) the fact that the 'behavioural revolution' that had lasting repercussions for American IR, did not take a solid hold of the British IR community. Where normative and empirical forms of political inquiry had come to be viewed in American IR as separate and markedly different enterprises, with the latter emerging as overwhelmingly dominant, there was no similar decoupling in British IR. The empirical work conducted by writers who established what is known as the 'English School,' or the international society perspective, was comparative-historical and its interpretive methods were less at variance with normative analysis than American proclivities towards scientific hypothesis-testing. Those associated with the English school, recognizing the mark scientific theories were making upon the discipline, laboured to demonstrate the paucity of empirical work pursued independently of thought about standards for evaluating international political action. Theirs was a 'classical approach' as Hedley Bull called it and he distinguished it from the new orthodoxy of the scientific approach in American IR, which held:

assumptions, in particular about the moral simplicity of problems of foreign policy, the existence of 'solutions' to these problems, the receptivity of policy-makers to the fruits of research, and the degree of control and manipulation that can be exerted over the whole diplomatic field by any one country. (Bull 1966: 376) 
By the late 1970s, British IR scholar James Mayall was writing that "we have seen the collapse of this 'value-free' social science and now accept that values have to be brought into IR theory, the question is how" (1978: 122).

One answer to this 'how' question was the development of normative IR theory in the UK, in part as a response to perceived deficiencies within English School itself. The English school did not eschew ethical judgement altogether, but it often allowed its historical analysis of the actually-existing pattern of international order to dominate its views on the reasonableness of different ethical choices, particularly between the intersocietal values of order and justice and often prioritized order in the context of the Cold War. While they saw normative analysis as necessary to inquiry into the nature of international society, the English school's capacity for normative theorizing was limited by their unwillingness to make judgements when values conflicted, either across moral traditions in Western thought or across plural cultural traditions in diverse political societies. Theirs was a propensity for 'detachment' and the less controversial task of laying out a rich panoply of patterns in which humans have reflected on the world and its organization (Wight 1991). The school did not have an answer to the 'how' question and avoided moral-philosophical reasoning, prompting the growth of normative IR in the UK. The critique that emerged of the School from normative IR was for its presumption of the good of the society of states because of the order it creates (Frost 1996: 115). Normative IR challenged the School to defend what normative value there is in international society and to think about an alternative organizing concept for the study of IR: what if we put justice rather than order at the centre of our inquiries into world affairs. The difficulty is that the English school lacked a method for doing this kind of inquiry, and constructivists have the same problem today.

Even though Ruggie had the English school in mind when he said that he would not include under his umbrella of "constructivism" those whose analysis failed to fall in line with the aims of American social science, many comparisons have been drawn between the English School and constructivism. ${ }^{18}$ I am going to offer another, a suggestion that has yet to be made: neither of these approaches is self-consciously pragmatist in a methodological sense, but both encounter the same obstacle in their efforts to theorize change in international society, and the impact of change on the international norms which are the bread and butter of what each does. How is change to be directed? What is the moral or social value of norms, and what is lost, what is gained in the course of change? English school and constructivist scholars who are genuinely interested in such questions will have to study norms in the context of their normativity; that is, the processes of valuation that go on in the practices of international society. Both the English school and constructivists should be more interested in how valuation is done. Here is where pragmatism has more to offer than has hitherto been appreciated.

As noted above, one of the lessons that IR scholars have taken from pragmatism is to let methodological pluralism thrive; but this should extend too to the pragmatist research strategies from which we draw. Dewey offers a method of normative social inquiry that brings together empirical and normative lines of inquiry backed by a philosophy of valuation. Abduction is one method to be drawn from pragmatism, and I do not doubt that Friedrichs and Kratochwil are right that it is a "good bet." Yet, if social scientific knowledge is purposeful, and the value of such knowledge is determined by "how it enables orientation in the social world, including the tractability of relevant social problems" (Friedrichs \& Kratochwil 2009: 706), then consideration is essential of the role 
moral judgment plays not only in the act of seeking knowledge for purposes of orientation, but in thinking about the tractable in world politics and what action might be taken in relation to it. This suggests that valuation too could be an important pragmatist research tool in assisting orientation in the social world. We should not let the idea drop, perhaps out of residues of dichotomous fact/value, empirical/normative thinking, that other avenues of pragmatist research may be worthy of our interest and Dewey's valuation is one such method. As Peter Manicas wrote in the first volume of the symposia:

Dewey believed, rightly, that human sciences could help us to understand ourselves: how we think and inquire and why, when thinking and inquiry is successful, it is successful. They would give us insight into what were our genuine interests and purposes and their relations, and most obviously, they would give us an understanding of the obstacles in present arrangements that keep us from realizing our genuine interests and purposes. (Manicas 2011: 16)

For their different reasons, when scholars of the English School, constructivism or any other, even pragmatist-inspired, approach to IR conclude that there is little point in inquiring into the nature of values in international relations, what is good or what is bad, they are missing a key point of Dewey's philosophy. There is no problem of knowledge in relation to the truth of a value; there is instead, warranted assertability to be found in the clues provided in the particular social values of the communities sharing in a problem, clues which are rendered through a working method of inquiry. The aim of Dewey's method is formulated simply too: to illuminate what our actually existing purposes are and the obstacles in their way as we work to adapt better to our changing world. As Dewey writes, our ends-in-view are but hypotheses to be tested in present conditions and can alter our ways of dealing with social issues for the better or not (LW 12: 491). The proof, or warranted assertablility, is in the doing and in the outcomes of their application helpfully working for those concerned.

41 Thus, what distinguishes the philosophy of valuation and the method of Deweyan inquiry in IR is its scrutiny of: 1 ) social values and the reasoning associated with those values; 2 ) the interrelation of social values with the facts of problems found in international society; and 3) a critical method of intelligence with a view towards uncovering, or constructing where needed, an integrative value for improved problem-solving in the management of international society. Efforts at valuation in future research could add insight into what social values are at play in contemporary international affairs, and how an expansion of value horizons might facilitate the creation of a coherent conceptual framework for articulating common goals within the international practice of issue domains, like nuclear weapons or climate change, where there is clearly an acute problematic situation, but no agreement on what exactly the problem is among the parties who share in the problem.

\section{Conclusion}

Since the positivist grip on the discipline of IR has loosened, numerous approaches have found space within which to develop: constructivism, a revitalized English school, and normative approaches drawing upon a range of thinking from classical international political thought to Frankfurt School critical theory, French poststructuralism, feminism, and American pragmatism too. Each of these new approaches shares Dewey's conviction that social learning can and does take place at the international level in response to 
changed international conditions. International institutions and international norms have grown more extensive and encompassing in the years since the classical pragmatists were writing. Do international social conditions today reflect what the liberal internationalists aimed to describe and understand, the possibility of making social institutions better with the ends of individuals in view? Is there scope for thinking about justice as well as anarchy in the study of international relations? On the long view, writers like Osiander (1998) believe the so-called 'idealists' performed better at seeing the future of IR than the realists of that first great debate in IR.

It has been the claim of this article, that in the early days of the discipline pragmatism did not really feature, but for Dewey's indirect contribution to the theory of the state. However, this contribution was not insignificant. It holds many lessons for the pluralisms that were to follow ${ }^{19}$ in the ontological sense of what counts for study in the discipline. The shame is the disconnect created by the epistemological proclivities of IR when those new pluralisms were flourishing; there was no hook up to those lessons and so pragmatism's relevance only really surged when the discipline began to break free from the dominance of positivism. The discipline first turned to pragmatism as a critique of the assumptions of positivism, and to shape its calls for methodological pluralism. A further shame would be to leave it there. There is more that pragmatism has to offer: Dewey's philosophy of valuation and method of normative social inquiry was the one highlighted here. There may be others. But note that when we look back to the key formative moment of the IR discipline after WW I, and we cannot seem to find pragmatism there, even at a time when its philosophy was ascendant, a new, still plastic discipline was on the rise, and that philosophy was speaking to it, one can only call it a missed opportunity. Now, here comes another opportunity. IR is calling you, the philosophers of pragmatism. Sil and Katzenstein admit that their borrowings from pragmatism are crude and that they will need assistance in its application to analytic eclecticism along the way. The substantive concerns of James and Dewey at least stand as evidence that there is no reason why philosophers should turn away from international problems. Will philosophical pragmatists demonstrate an interest in international relations once again?

\section{BIBLIOGRAPHY}

Aalto P., (2011), "Pragmatic Foreign Policy: Managing Power Differentials in the Wide European Society of States," Astrov A. (ed.), The Great Power (Mis)Management: the Russian-Georgian War and its Implications for Global Political Order, Farnham, Ashgate Publishing Ltd.

ASHWORTH L. M., (1999), Creating International Studies: Angell, Mitrany and the Liberal Tradition, Aldershot, Ashgate Publishing Ltd.

BANKS M., (1984), “The Evolution of International Relations Theory,” M. Banks (ed.), Conflict in World Society, New York, St. Martin's Press, 3-21.

BAUER H. \& E. BRIGHI, (2008), Pragmatism in International Relations, New York, Routledge. 
BELlAmy A., (2002), "Pragmatic Solidarism and the Dilemmas of Humanitarian Intervention," Millennium: Journal of International Studies 31, 473-98.

вонмаN J., (2002), “How to Make a Social Science Practical: Pragmatism, Critical Social Science and Multiperspectival Theory," Millennium: Journal of International Studies 31, 499-524.

BOHMAN J., (2005), Democracy Across Borders: from Demos to Demoi, Cambridge, Massaschusettes Institute of Technology Press.

BOUCHER D., (1998), Political Theories of International Relations: from Thucydides to the Present, Oxford, Oxford University Press.

BRAY D., (2011), Pragmatic Cosmopolitanism: Representation and Leadership in Transitional Democracy, London, Palgrave Macmillan.

BROWN C., (1997), “Universal Human Rights: A Critique," International Journal of Human Rights 1, 41-65.

BROWN C., NARDIN T, \& N. RENNGER (eds.) (2002), International Relations in Political Thought: Texts from the Ancient Greeks to the First World War, Cambridge, Cambridge University Press.

BRUNKHORST H., (2002), “Globalising Democracy Without a State: Weak Public, Strong Public, Global Constitutionalism," Millennium: Journal of International Affairs 31, 675-90.

BULL H., (1966), “International Theory: The Case for a Classical Approach,” World Politics, 18 (3), 361-77.

BUZAN B., (2001), “The English School: an Underexploited Resource in IR,” The Review of International Studies 27, 471-88.

CARR E. H., (1939), The Twenty Years' Crisis: An Introduction to the Study of International Relations, Oxford, Clarendon Press.

CHECKEL J., (2005), “International Institutions and Socialization in Europe: Introduction and Framework," International Organization 59, 801-26.

CHECKEL J., (2007), “Constructivism and EU Politics,” Handbook of European Union Politics, Joergensen, K., Pollack, M. \& Rosamond, B. (eds.), London, Sage.

CHERNOFF F., (2004), “The Study of Democratic Peace and Progress in International Relations," International Studies Quarterly 6, 49-77.

COCHRAN M., (1996), "Is There a Role for the Liberal Ironist in IR Theory?," Millennium: Journal of International Studies 25, 29-52.

Cochran M., (2000), "What Does it Mean to be an American Social Science? A Pragmatist Case for Diversity in International Relations," in Robert Crawford \& Darryl Jarvis (eds.), International Relations: Still a Social Science, Albany, State University Press of New York.

Cochran M., (2001a), “A Pragmatist Perspective on Ethical Foreign Policy,” in Smith K. \& Light M. (eds.), Ethics and Foreign Policy: Theory and Practice, Cambridge, Cambridge University Press, 55-72.

COCHRAN M., (2001b), “Rorty's Neo-pragmatism: Some Implications for International Relations Theory," in Festenstein M. \& Thompson S. (eds.), Richard Rorty: Critical Dialogues, Cambridge, Polity Press, 176-99.

Cochran M., (2002a), “A Democratic Critique of Cosmopolitan Democracy,” European Journal of International Relations 8, 517-48. 
COCHRAn M., (2002b), “Deweyan Pragmatism and Post-Positivist Social Science in IR," Millennium: Journal of International Affairs 31, 525-48.

Cochran M., (2008), "Conceptualizing the Power of Transnational Agents: Pragmatism and International Public Spheres," Geenens R. \& Tinnevelt R. (eds.), Does Truth Matter? Democracy and Public Space, Dordrecht, Springer.

Cochran M., (2010), “John Dewey as an International Thinker," M. Cochran (ed.), The Cambridge Companion to John Dewey, Cambridge, Cambridge University Press, 309-36.

CRABB C., (1989), American Diplomacy and the Pragmatic Tradition, Baton Rouge, Louisiana State University Press.

DEWEY J., (1929), Characters and Events: Popular Essays in Social and Political Philosophy, Volumes I and II , R. Ratner (ed.), New York, H. Holt and Co.

DEWEY J., (2003), The Collected Works of John Dewey, 1882-1953, Electronic Edition, Charlottesville, InteLex Corporation.

DRISCOLL J. \& C. HYNEMAN, (1955), "Methodology for Political Scientists: Perspectives for Study," American Political Science Review 49, 192-217.

FESTENSTEIN M., (2002), “Pragmatism's Boundaries,” Millennium: Journal of International Affairs 31, $549-72$.

FINNEMORE M., (1996), National Interests in International Society, Ithaca, Cornell University Press.

FINNEMORE M., (2003), The Purpose of Intervention: Changing Beliefs about the Use of Force, Ithaca, Cornell University Press.

FINNEMORE M. \& K. SIKKINK, (1998), "International Norm Dynamics and Political Change," International Organization 52, 887-917.

FRANKE U. \& U. ROOS, (2010), “Actor, Structure, Process: Transcending the State Personhood Debate by Means of a Pragmatist Ontological Model for International Relations Theory," Review of International Studies 36, 1057-77.

FRIEDRICHS Jörg \& F. KRATOCHWIL, (2009), “On Acting and Knowing: How Pragmatism Can Advance International Relations Research and Methodology," International Organization, 63, 701-31.

FROST M., (1996), Ethics in International Relations: A Constitutive Theory, Cambridge, Cambridge University Press.

FOX W. T. R., (1967), “Interwar International Relations Research: The American Experience,” The American Study of International Relations: Essays by William T. R. Fox, Columbia, University of South Carolina Press, 1-13.

GOULD H. \& N. ONUF, (2008), "Pragmatism, Legal Realism, and Constructivism," Pragmatism in International Relations, Bauer H. \& Brighi E., New York, Routledge.

HAAS E. \& P. HAAS, (2008), "Pragmatic Constructivism and the Study of International Institutions," Pragmatism in International Relations, Bauer H. \& Brighi E., New York, Routledge; and (2002) in Millennium: Journal of International Affairs 31, 573-602.

HALLIDAY F., (1994), Rethinking International Relations, Basingstoke, Macmillan.

HellmanN G., (2003). "Forum: Are Dialogue and Synthesis Possible in International Relations?," International Studies Quarterly 5, 123-52. 
HINSLEY F. H., (1963), Power and the Pursuit of Peace: Theory and Practice in the History of Relations Between States, Cambridge, Cambridge University Press.

ISACOFF J., (2005), "Writing the Arab-Israel Conflict: Historical Bias and the Use of History in Political Science," Perspectives on Politics 3, 71-88.

JACKSON P. T., (2009), "Situated Creativity, or, the Cash Value of a Pramgatist Wager for IR," International Studies Review 11, 656-9.

JACKSON P. T., (2011), The Conduct of Inquiry in International Relation: Philosophy of Science and its implication for the Study of World Politics, London, Routledge.

JAMES W., (2008), The Works of William James, Electronic Edition, Charlottesville, InteLex Corporation.

KAPLAN M., (1957), System and Process in International Relations, New York, John Wiley and Sons.

KAPLAN M., (1961), “Is International Relations a Discipline?,” Journal of Politics 23, 462-76.

KAPLAN M., (2000), “My Post-Postmodern Objective Account of Theory and Moral Analysis," Review of Politics 62, 675-706.

KEENE E., (1995), International Political Thought: A Historical Introduction, Cambridge, Polity Press.

KLOTZ A., (1995), Norms in International Relations: The Struggle against Apartheid, Ithaca, Cornell University Press.

KORNPROBST M., (2009), "Doing What Comes Naturally Without Being Oblivious To It: Rhetorical Pragmatism and International Relations," International Studies Review 11, 652-5.

KNUTSEN T., (1992), A History of International Relations Theory: An Introduction, Manchester, Manchester University Press.

KRATOCHWIL F., (2007), “Of False Promises and Good Bets: A Plea for a Pragmatic Approach to Theory Building," Journal of International Relations and Development, 10 (1), 1-15.

KRATOCHWIL F., (2011), “Ten Points to Ponder about Pragmatism," The Puzzles of Politics: Inquiries into the Genesis and Transformation of International Relations, Abingdon, Routledge, 200-16.

KURKI M., (2008), Causation in International Relations: Reclaiming Causal Analysis, Cambridge, Cambridge University Press.

LAPID Y., (1989), “The Third Debate: On the Prospects of International Theory in a Post-positivist Era," International Studies Quarterly 33, 235-54.

LASKI H., (1921), The Foundations of Sovereignty and Other Essays, London, George Allen Unwin.

LASKI H. J., (1927), “International Government and National Sovereignty,” The Problems of Peace, Oxford, OUP, 288-312.

LONG D. \& P. WILSON (eds.), (1995), Thinkers of the Twenty Years' Crisis: Inter-war Idealism Reassessed, Oxford, Clarendon Press.

LONG D., (1995), “Conclusion: Inter-war Idealism, Liberal Internationalism, and Contemporary International Theory," Thinkers of the Twenty Years' Crisis: Inter-war Idealism Reassessed, Long D. \& Wilson P. (eds.), Oxford, Clarendon Press.

MANICAS P., (2011), “American Social Science: The Irrelevance of Pragmatism,” European Journal of Pragmatism and American Philosophy 3, 1-23.

MAYALL J., (1978), “International Society and International Theory," The Reason of States, Donelan M. (ed.), London, George Allen and Unwin. 
OLSON W. C., (1972), "The Growth of the Discipline," The Aberystwyth Papers: International Politics 1919-69, Brian Porter (ed.), London, Oxford University Press.

OLSON W. C. \& A. J. R. GROOM, (1991), International Relations Then and Now: Origins and Trends in Interpretation, London, Harper Collins.

OSIANDER A., (1998), “Rereading Early Twentieth Century International Relations Theory: Idealism Revisited," International Studies Quarterly 42, 409-32.

OWEN D., (2002), "Re-orienting International Relations: On Pragmatism, Pluralism and Practical Reasoning," Millennium: Journal of International Studies 31, 653-74.

PARKER O. \& J. BRASSATT, (2005), “Contingent Borders, Ambiguous Ethics: Migrants in (International) Political Theory," International Studies Quarterly 49, 233-53.

PORTER B., (1989), “David Davies: a Hunter After Peace,” The Review of International Studies 15, 27-36.

PUCHALA D. J., (1995), “The Pragmatics of International History,” Mershon International Studies Review 39, 1-18.

REUS-SMIT C., (2002), "Imagining Society: Constructivism and the English School," The British Journal of Politics and International Relations, 4 (3), 487-509.

RUGGIE J., (1998a), Constructing the World Polity, New York, Routledge.

RUGGIE J., (1998b), "What Makes the World Hang Together? Neo-Utilitarianism and the Social Constructivist Challenge," International Organization 52, 855-85.

RYTOVUORI-APUNEN H., (2005), “Forget 'Post-Positivist' IR! The Legacy of IR Theory as the Locus for a Pragmatist Turn in IR," Cooperation and Conflict 40, 147-77.

RYTOVUORI-APUNEN H., (2009), “Abstractive Observation as the Key to the 'Primacy of Practice'," International Studies Quarterly 11, 641-5.

SCHмIDT B. C., (1998), The Political Discourse of Anarchy: A Disciplinary History of International Relations, Albany, State University of New York Press.

SIL R., (2009), "Simplifying Pragmatism: From Social Theory to Problem-driven Eclecticism," International Studies Review 11, 648-52.

SiL R. \& P. KATZEnstein, (2010), Beyond Paradigms: Analytic Eclecticism in the Study of World Politics, London, Macmillan Palgrave.

SMITH S., (1996), "Positivism and Beyond," International Theory : Positivism and Beyond, Smith S., Booth K., \& Zalewski M. (eds.), Cambridge, Cambridge University Press, 11-44.

WALTZ K., (1979), Theory of International Politics, Boston, Addison-Wesley.

WENDT A., (1992), “Anarchy is What States Make of It: the Social Construction of Power Politics," International Organization 46, 391-425.

WENDT A., (1999), Social Theory of International Politics, Cambridge, Cambridge University Press.

WHEELER N., (1997), “Agency, Humanitarianism, and Intervention,” International Political Science Quarterly 18, 9-25.

WHEELER N. \& T. DUNNE, (1998), "Hedley Bull and the Idea of a Universal Moral Community: Fictional, Primordial or Imagined?," International Society and the Development of International Relations Theory, Roberson B. (ed.), London, Pinter Press, 43-58. 
WIDMAIER W., (2004) "Theory as a Factor and the Theorist as an Actor: The 'Pragmatist Constructivist': Lessons of John Dewey and John Kenneth Galbraith," International Studies Review 6, 427-45.

WIGHT M., (1966), “Why is There No International Theory," Diplomatic Investigations Butterfield H. \& M. Wight (eds.), London, George Allen and Unwin, 200-16.

WIGHT M., (1991), International Theory: The Three Traditions, Leicester, Leicester University Press. WILliams H., (1991), International Relations in Political Theory, Milton Keynes, Open Univeristy Press. WILSON P., (1998), "The Myth of the 'First Great Debate'," Review of International Studies 24, 1-15. wood S., (2011), “Pragmatic Power Europe," Cooperation and Conflict 46, 242-61.

ZIMMERN A., (1936), The League of Nations and the Rule of Law, 1918-35, London, Macmillan.

\section{NOTES}

1. John McDermott writes in the introduction to William James's Essays in Religion and Morality that "the ideas put forward in James's essay were taken up in the United States on two occasions. First, during the depression of the 1930s the Civilian Conservation Corps was modeled after James's plan. (In fact, under the leadership of a philosopher, Eugene Rosenstock-Huessy, one such camp in New Hampshire was called Camp William James.) A second affirmation of James's viewpoint occurred with the founding of the Peace Corps during the presidential administration of John F. Kennedy. The Peace Corps was structured as an alternative to conscription, and the influence of James's essay was cited on behalf of that bold political move" (James 1982: xxvi).

2. David Davies, the founder of The Woodrow Wilson Chair, was motivated in this way and the Chair was intended in part as a memorial to students of the university who died in the Great War. See Porter 1989.

3. Histories of the discipline surveyed include: Asworth 1999; Banks 1984; Boucher 1998; Fox 1968; Hinsley 1963; Hinsley 1963; Kaplan 1961; Keene 2005; Knutsen 1992; Long \& Wilson 1995; Olsen 1972; Olson \& Groom 1991; Osiander 1998; Schmidt 1998; Williams 1991. I have excluded from this survey scholarship in the field of diplomatic history, which is of course related to, but has always been something apart from IR, given the social scientific aspirations of the latter. Worthy of note within this genre is Crabb 1989, American Diplomacy and the Pragmatic Tradition.

4. After making clear the use of pragmatism, small 'p,' in IR as distinct from the American philosophy, I will now revert to writing of the philosophical tradition in the more typical way, without a capital "P."

5. This point is made by Peter Katzenstein in the introduction to his volume, The Culture of National Security: Norms and Identity in World Politics (1996).

6. Willoughby as quoted in Schmidt (1998: 88).

7. Schmidt writes the idea that the study of IR consists principally of "issues arising from the existence of sovereign states in the absence of a higher central authority" gives the discipline its "distinct discursive identity" (1998: 41).

8. Willoughby as quoted in Schmidt (1998: 88).

9. Dewey reflects again on the theory of the state, invoking Austin in his 1888 essay, "The Ethics of Democracy" (EW 1: 227-49). In making his argument for an organic conception of society in which "society exists for and by individuals," Dewey writes, "[t]he English theory, as presented by Hobbes and worked out by Austin, virtually makes it [sovereignty] consist in irresponsible power (EW 1: 236). Interestingly, in this same essay, Dewey also remarks on J. C. Bluntschli's organism, and Schmidt refers to Blunschli as a contributor to the theoretical discourse of the 
state that influenced IR. Clearly, Dewey was a participant in this scholarly debate within political science in a way he did not seem to be as IR got underway post WW I.

10. Ellis as quoted in Schmidt (1998: 164).

11. The use of the term, 'international mind' by Dewey in this essay and others (e.g. "Emancipation of the International Spirit," LW 3: 349) demonstrates his emersion in the scholarship of the liberal internationalists who were building IR, since the concept features in important works by two early notables in IR, Alfred Zimmern and Nicholas Murray Butler (also the President of Columbia University who hired Dewey and brought him to New York in February of 1905).

12. As quoted in Schmidt (1998: 165$)$.

13. Indeed, Carr is credited with framing the first great debate in IR between idealism and realism, the effects of which have been so lasting that articles and books are still being written today challenging its thesis that the idealists or utopians - as the liberal internationalists were labeled - were out of touch with the realities of world politics. Schmidt's attention to pluralism and its significance for the pre-history of IR does the discipline the great favor of reminding it that the liberal internationalists built their contribution to the discipline challenging what was perceived to be reality then. In addition to Schmidt, see Wilson 1998 and Osiander 1998.

14. I have found one other reference to pragmatism from this period in a 1955 review article on methodology for political science which argues in a section on "The Problem of Knowledge," that a grounding in the philosophic aspects of method (rationalism, empiricism, positivism, logical positivism) is important. It refers readers to Dewey and Bentley's co-authored book, Knowing and the Known (largely because of Bentley's early work on the processes of government being of interest to political scientist), but urges readers to dig deeper and look at almost anything within pragmatism to gain a background in what "has been so influential in the philosophy of science and social science" (Driscoll and Hyneman, 1955: 14). In America at this time and still today, IR is a subfield taught within political science departments at most universities.

15. John Burton, an Australian diplomat who became a UK-based academic, developed a 'world society' approach that was inspired by behavioralism, but he employed it for purposes different than those found in the US. Where behavioralism served to provide a more scientific basis for realism in the US, 'world society' theorists used behavioralism to challenge the state-centric assumptions of realists, including those of the English school. They also employed it differently in the sense that they were less zealous in regard to quantification (Banks 1984).

16. Pierce is also invoked in another context by Fred Chernoff (2004), who draws upon Pierce's account of scientific progress to demonstrate that the literature on the democratic peace theory has achieved 'progress' of a kind found in the natural sciences.

17. In Sil and Katzenstein (2010: 45-7), the authors offer four broad pragmatist ideas about social inquiry that have influenced their work. The first principle is by and large the same as above. The second, principle is the third in the 2010 version. Mead and symbolic interactionism remain, but another pragmatist principle is added: that knowledge must adapt to novel experiences and changing circumstances.

18. Scholars in the UK who have written about the English School's constructivist credentials include Dunne 1995, 1998; and Buzan 2001. American constructivists who acknowledge early constructivist insights in the work of the English School include: Klotz 1995; Finnemore 1996; Ruggie 1998; Keck \& Sikkink 1998. For a view from an Australian who has spent time in both contexts and thought about the synergies of each approach, see Reus-Smit C. 2002. This engagement has done much to revitalize the English school since the passing of its key members; in fact, a new English School section of the International Studies Association was created in 2003.

19. For example, see Long (1995: 321-2). 


\section{ABSTRACTS}

The discipline of International Relations [IR] is experiencing a pragmatist turn. Here I will argue that this is a critical moment to take stock and reflect on where it is heading. First, in order to understand what pragmatism might bring to IR as a social science today, it is important to examine the history of IR and explain why pragmatism appears not to have registered in its past. Why have the contributions of Wiliam James and, especially, John Dewey apparently disappeared from the early history of the field? Secondly, having examined what the problem was before, I go on to argue that the opportunity that exists today for pragmatism to influence the field is constructed upon its critique of empiricist epistemology, its scope for bridging plural methods, and the broadening of our understanding of what international relations is, opening the range of possible ontological claims which the discipline finds necessary at this time.

\section{AUTHOR}

\section{MOLLY COCHRAN}

Visiting Fellow, Institute for Ethics, Law and Armed Conflict, University of Oxford molly.cochran[at]inta.gatech.edu 